\title{
Intradural Extramedullary Ganglioneuroma Associated With Multiple Hamartoma Syndrome
}

\author{
-Case Report- \\ Rinsei Tei, Tetsuya Morimoto, Kazunori Miyamoto, Shuta AKeta, \\ Tatsuo SHIMOKAWARA, Yasushi SHIN, and Yasuo HIRONAKA \\ Department of Neurosurgery, Osaka Police Hospital, Osaka
}

\begin{abstract}
A 51-year-old woman presented with a rare completely intradural and extramedullary spinal ganglioneuroma associated with multiple hamartoma syndrome and manifesting as complaints of neck pain and dizziness persisting for 8 months. Magnetic resonance imaging of the spinal cord revealed an intradural extramedullary lesion at the $\mathrm{C} 1$ level. She underwent right suboccipital craniectomy and C1-2 hemilaminectomy to remove the tumor. Histological examination confirmed ganglioneuroma. She also suffered from multiple facial trichilemmomas, thyroid goiter, multiple polyposis of the gastrointestinal tract, and pulmonary hamartoma indicating multiple hamartoma syndrome. These benign neoplasms were treated conservatively.
\end{abstract}

Key words: intradural ganglioneuroma, spinal neoplasm, surgical treatment, multiple hamartoma syndrome

\section{Introduction}

Ganglioneuroma arises from the ganglion cells of the sympathetic nervous system, and infrequently from the sympathetic nerves or other peripheral nerves. ${ }^{\left.1{ }^{12}\right)}$ Females are more affected than males. ${ }^{11)}$ These slow-growing benign neoplasms contain welldifferentiated ganglion cell stroma resembling neurofibroma and are common in the posterior mediastinum but may occur in the cervical region, retroperitoneal region, adrenal glands, and sympathetic ganglion. ${ }^{7,12,13)}$ Ganglion cell tumors originate in a defect in developmental embryogenesis, with multipotent embryonal neurocytes deposited in abnormal positions. ${ }^{17)}$ Complete removal of a ganglioneuroma is usually curative. ${ }^{6)}$ Ganglioneuromas are rarely located in the spinal cord, ${ }^{4,10,14)}$ and are frequently dumbbell-shaped. ${ }^{9,15}$ Spinal ganglioneuroma is usually benign in nature and remains asymptomatic until large enough to compress the spinal cord and nerves, resulting in localized pain, radiculopathy, and weakness of the extremities. ${ }^{3)}$

We present a case of mature ganglion cell tumor within the intradural space of upper cervical spine

Received December 14, 2006; Accepted August 22, 2007 and manifesting as neck pain and dizziness. The patient also suffered from multiple facial trichilemmomas, thyroid goiter, multiple polyposis of the gastrointestinal tract, and pulmonary hamartoma.

\section{Case Report}

A 51-year-old woman presented with complaints of neck pain and progressive dizziness persisting for 8 months. Neurological examination revealed no motor weakness or sensory disturbance. Magnetic resonance imaging of the spinal cord showed an intradural extramedullary lesion at the $\mathrm{C} 1$ level appearing as isointense or slightly hypointense on $\mathrm{T}_{1-}$ weighted images and hyperintense to the spinal cord on $\mathrm{T}_{2}$-weighted images, with enhancement by contrast medium (Fig. 1).

The patient underwent right suboccipital craniectomy and C1-2 hemilaminectomy. The dura was opened and the dentate ligament was resected to reveal a well-circumscribed, extramedullary, ovalshaped mass. The mass was attached to the $\mathrm{C} 1$ ventral root, and was totally excised. Histological examination revealed large ganglion cells with large vesicular nuclei and prominent eosinophilic nucleoli and spindle-shaped cells arranged in fascicles (Fig. 2A). Immunohistochemical staining with a panel of 


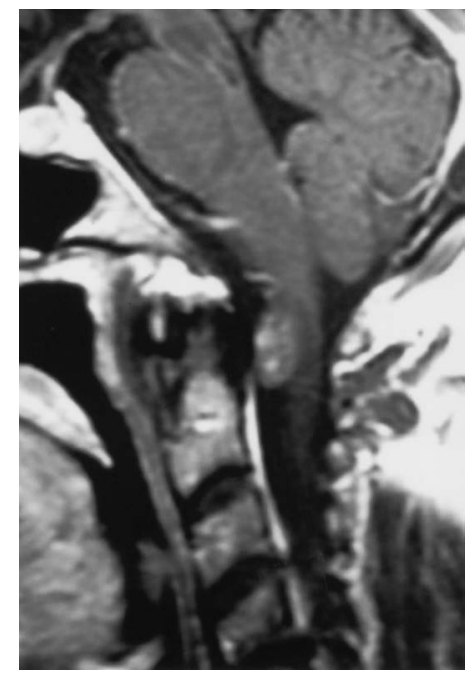

Fig. 1 Sagittal $T_{1}$-weighted magnetic resonance image of the spinal cord with contrast medium showing an enhanced intradural extramedullary lesion at the C1 level.
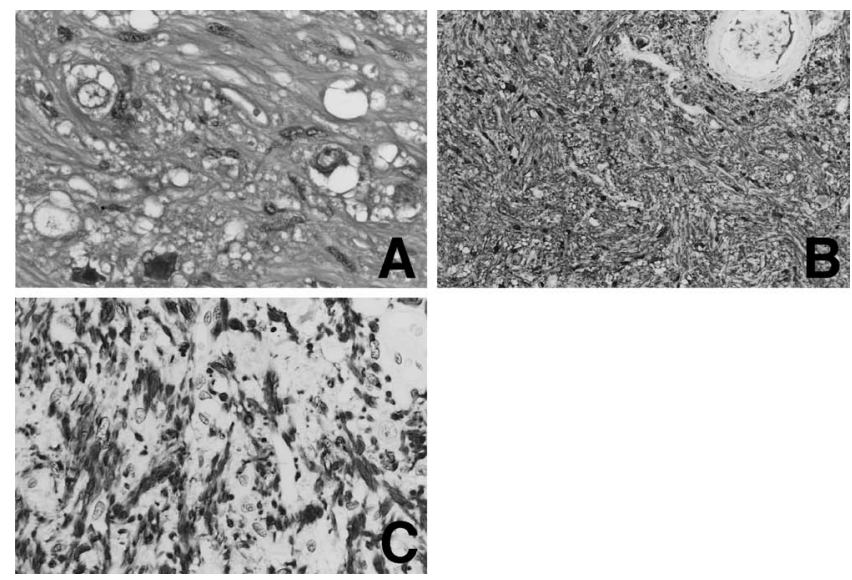

Fig. 2 A: Photomicrograph revealing large ganglion cells with large vesicular nuclei and prominent eosinophilic nucleoli and spindle-shaped cells arranged in fascicles. Hematoxylin and eosin stain, $\times 400$. B: Photomicrograph showing positive immunoreaction for S-100 protein in the ganglion cells. $\times 100$. C: Photomicrograph revealing positive immunoreaction for neurofilament in the ganglion cells. $\times \mathbf{4 0 0}$.

monoclonal antibodies revealed positive reaction for S-100 protein (Fig. 2B), and neurofilament (Fig. 2C) in the ganglion cells. The final histological diagnosis was ganglioneuroma. In the pathological findings, MIB-1 labeling index was less than $1 \%$.

Examination of the patient's skin revealed a large number of hyperkeratotic lichenoid papules, 1 to 3 $\mathrm{mm}$ in diameter, scattered over the forehead, cheeks, and chin. The patient had also suffered from multiple facial trichilemmomas, thyroid goiter, multiple polyposis of the gastrointestinal tract, and pulmonary hamartoma. Associated benign neoplasms were found incidentally, and were treated conservatively. The patient denied any similar skin lesions or significant medical problems in other family members, including her two children. She refused to allow examination of any family members.

\section{Discussion}

Only one case of pure intradural extramedullary ganglioneuroma has been reported.6) The present case of mature ganglion cell tumor was located within the dura of the upper cervical spine and outside the spinal canal. We speculate that the ectopic tumor which underwent hamartomatous change originated in the intradural space but without the normal dumbbell-shaped growth pattern as a part of multiple hamartoma syndrome. Hamartomas also present as a part of multiple endocrine neoplasia (MEN) and could be associated with von Recklinghausen disease. ${ }^{16)}$ The tumors of MEN occur in the adrenal medulla, pancreas, and pituitary together with ganglioneuromas in the mediastinal and retroperitoneal regions. ${ }^{5,18)}$ The diagnosis of these tumors is usually based on the clinical presentation and neuroimaging findings. ${ }^{2)}$

Histological examination revealed a neoplastic lesion consisting of spindle-shaped cells arranged in fascicles. The cells contained abundant faintly eosinophilic cytoplasm and indistinct boundaries. The nuclei were serpentine exhibiting minimal hyperchromasia and pleomorphism. Large ganglion cells with large vesicular nuclei and prominent eosinophilic nucleoli were interspersed between the spindle-shaped cells. No significant mitotic activity was found. The ganglion cells were positively stained for S-100 protein and neurofilaments. ${ }^{2,6)}$

Cowden disease or multiple hamartoma syndrome is a rare autosomal dominant condition characterized by a complex mixture of endodermal, mesodermal, and ectodermal hamartomatous lesions. The pathognomonic hamartomatous features include multiple smooth facial papules, acral keratosis, and multiple oral papillomas. The facial papules are characterized by multiple trichilemmomas. Central nervous system manifestations were emphasized only recently and include megalencephaly, epilepsy, and dysplastic gangliocytomas of the cerebellum (Lhermitte-Duclos disease). Other lesions include benign and malignant diseases of the thyroid, intesti- 
nal polyps, and genitourinary abnormalities. ${ }^{8)}$ Our patient also seemed to suffer from multiple hamartoma syndrome with ganglioneuroma, multiple facial trichilemmomas, thyroid goiter, multiple polyposis of the gastrointestinal tract, and pulmonary hamartoma, which were found incidentally and were asymptomatic. She was treated conservatively for these other lesions. We speculate that though the ganglioneuroma was incidentally found, it was inevitably associated with multiple hamartoma syndrome.

\section{References}

1) Belzberg AJ, Campbell JN: Neoplasms of peripheral nerves, in Wilkins RH, Rangachary SS (eds): Neurosurgery, vol III, ed 2. New York, McGraw-Hill, 1996, pp 3217-3223

2) Bhand AA: Ganglioneuroma of the cervical spine. J Coll Physicians Surg Pak 15(2): 114-116, 2005

3) Claifo L, Zulpi A, Mangone GM, Long F: Ganglioneuroma: report of a case. Otolaryngol Head Neck Surg 124: 115-116, 2001

4) Kalyanaraman UP, Henderson JP: Intramedullary ganglioneuroma of spinal cord: a clinicopathologic study. Hum Pathol 13: 952-955, 1982

5) Kyoshima K, Sakai K, Kanaji M, Oikawa S, Kobayashi S, Sato A, Nakayama J: Symmetric dumbbell ganglioneuromas of bilateral $\mathrm{C} 2$ and $\mathrm{C} 3$ roots with intradural extension associated with von Recklinghausen's disease: case report. Surg Neurol 61: 468-473, 2004

6) Levy DI, Bucci MN, Weatherbee L, Chandler WF: Intradural extramedullary ganglioneuroma: case report and review of the literature. Surg Neurol 37: 216-218, 1992

7) Marchevesky A: Mediastinal tumors of peripheral nervous system origins. Semin Diagn Pathol 16: 65-78, 1999

8) Nelen MR, Padberg GW, Peeters EA, Lin AY, van den Helm B, Frants RR, Coulon V, Goldstein AM, van Reen MM, Easton DF, Eeles RA, Hodgsen S, Mulvihill JJ, Murday VA, Tucker MA, Mariman EC, Starink TM, Ponder BA, Ropers HH, Kremer H,
Longy M, Eng C: Localization of the gene for Cowden disease to chromosome 10q22-23. Nat Genet 13: 114-116, 1996

9) Oro JJ, Geise AW: Dumbbell ganglioneuroma of the lumbar spine associated with a herniated intervertebral disc: case report. Neurosurgery 13: 711-714, 1983

10) Rasmussen TB, Kernohan JW, Adson AW: Pathologic classification, with surgical consideration, of intraspinal tumors. Ann Surg 11: 513-529, 1940

11) Reschini E, Catania A, Airaghi L, Manfredi MG, Crosignani P: Scintigraphic study of extraadrenal ganglioneuroma in a patient with overlap between multiple endocrine neoplasia types 1 and 2. Clin Nucl Med 17: 573-576, 1992

12) Robertson DM, Hendry WS, Vogel FS: Central ganglioneuroma: a case study using electron microscopy. J Neuropathol Exp Neurol 23: 692-705, 1964

13) Rubinstein LJ: Tumors of the Central Nervous System, ed 2. Washington, DC, Armed Forces Institute of Pathology, 1972, pp 154-167

14) Scoville WB, Polcyn JL, Dunsmore RH: Spinal ganglioneuromas: end results and differential diagnosis. J Neuropathol Exp Neurol 15: 85-92, 1956

15) Shephard RH, Sutton D: Dumb-bell ganglioneuromata of the spine with a report of four cases. Br J Surg 45: 305-317, 1958

16) Sinclair JE, Yang YH: Ganglioneuromata of the spine associated with Von Recklinghausen's disease. J Neurosurg 18: 115-119, 1961

17) Stout AP: Ganglioneuromas of the sympathetic nervous system. Surg Gynecol Obstet 84: 101-110, 1947

18) Torre M, Martucciello G, Ceccherini I, Lerone $M$, Aicardi M, Gambini C, Jasonni V: Diagnostic and therapeutic approach to multiple endocrine neoplasia type $2 B$ in pediatric patients. Pediatr Surg Int 18: 378-383, 2002

Address reprint requests to: Rinsei Tei, M.D., Department of Neurosurgery, Osaka Police Hospital, 10-31 Kitayama-cho, Tennoji-ku, Osaka 543-0035, Japan. e-mail:nm150322@mahoroba.ne.jp 